\title{
PENGARUH KEPUTUSAN INVESTASI, CONTROLLING SHAREHOLDERS DAN KEBIJAKAN DIVIDEN TERHADAP CORPORATE VALUE
}

\author{
Fitri Yeni , Yosi Yulia , Yosetla Indah , Rindi Citra Dewi \\ Universitas Putra Indonesia YPTK Padang, Indonesia \\ Email : fitri_yeni@upiyptk.ac.id
}

\begin{abstract}
ABSTRAK
Tujuan penelitian ini adalah melihat pengaruh keputusan investasi, controlling shareholders dan kebijakan dividen terhadap corporate value (PBV) perusahaan. Sampel pada penelitian ini adalah perusahaan manufaktur yang terdaftar di Bursa Efek Indonesia sebanyak 131 perusahaan. Hasil penelitian menunjukkan bahwa keputusan investasi berpengaruh positif dan signifikan terhadap corporate value. Controlling shareholders dan kebijakan dividen tidak berpengaruh terhadap corporate value. Untuk variabel kontrol temuan penelitian menunjukkan bahwa firm size dan kinerja perusahaan tidak berpengaruh terhadap corporate value.

Primary Key : Keputusan Investasi, Controlling Shareholders, Kebijakan Dividen, Firm Size, Kinerja Perusahaan, Corporate Value
\end{abstract}

\section{Pendahuluan}

Kondisi perkembangan investasi menyebabkan suatu perusahaan terdorong untuk melakukan pengembangan pada proyek-proyek investasi guna meningkatkan corporate value. Dimana proyek-proyek tersebut berasal dari penanaman modal asing dan penanaman modal dalam negeri (domestik).

\section{Tabel 1}

Perkembangan Nilai Investasi Asing dan Nilai Investasi Dalam Negeri (Domestik)

\begin{tabular}{lllll}
\hline Tahun & $\begin{array}{l}\text { Nilai investasi } \\
\text { Asing Persentase } \\
(\text { Rp Triliun) }\end{array}$ & $\begin{array}{l}\text { Nilai investasi } \\
\text { Domestik } \\
\text { (Rp Triliun) }\end{array}$ & Persentase (\%) \\
\hline 2014 & $28.529,698$ & 0,99 & $156.126,157$ & 21,83 \\
2015 & $29.275,941$ & 1,02 & $179.465,867$ & 40,04 \\
2016 & $28.964,075$ & 1,01 & $216.306,086$ & 68,79 \\
\hline
\end{tabular}

Sumber: www.bkpm.co.id

Dari tabel di atas dapat dilihat bahwa nilai investasi asing pada tahun 2014-2016 di pasar modal mengalami fluktuasi. Hal ini disebabkan karena stabilitas nilai tukar rupiah terhadap mata uang negara lain, khusunya Amerika Serikat (AS) yang sangat dipengaruhi oleh kondisi global serta laju inflasi dengan suku bunga acuan perbankan terlalu besar. Sedangkan nilai investasi domestik mengalami peningkatan dari tahun ke tahun mencapai 68,79\% pada tahun 2016 dengan nilai investasi sebesar Rp 216.306,086 triliun. Maka dari itu perusahaan dituntut untuk meningkatkan corporate value.

Dengan meningkatnya corporate value berarti perusahaan juga meningkatkan kesejahteraan dan kemakmuran bagi pemegang saham, sebagaimana ini menjadi tujuan utama dari pendirian 
sebuah perusahaan. Apabila telah dimaksimalkan corporate value maka akan terlihat dari harga pasar sahamnya. Harga saham yang mengalami peningkatan dalam jangka panjang cenderung menjadikan corporate value meningkat. Corporate value yang semakin tingi mengindikasikan peningkatan laba bagi pemegang saham.

Corporate value dapat ditingkatkan dengan keputusan investasi yang baik. Keputusan investasi merupakan faktor penting dalam fungsi keuangan perusahaan, karena untuk mencapai tujuan perusahaan dapat dicapai melalui kegiatan investasi perusahaan. Investasi modal merupakan salah satu aspek utama dalam keputusan investasi selain penentuan komposisi aktiva.

Menurut Rinnaya dkk (2016), manajer perusahaan dalam melakukan keputusaninvestasi pastinya telah memperhitungkan return yang akan diterima. Keputusan investasi yang diharapkan adalah keputusan investasi yang paling menguntungkan perusahaan. Perusahaan dapat meningkatkan corporate value dengan mengurangi informasi asimetri yaitu dengan memberikan sinyal pada pihak luar, salah satunya berupa informasi keuangan yang positif dan dapat dipercaya yang akan mengurangi ketidakpastian mengenai prospekperusahaan yang akan datang sehingga dapat meningkatkan kredibilitas dan kesuksesan perusahaan. Faktor lain yang mempengaruhi corporate value adalah controlling shareholders.

Menurut Setianto dan Putri (2017) keluarga adalah jenis pemegang saham pengendali (controlling shareholder) yang paling banyak ditemui. Kehadiran keluarga sebagai controlling shareholder dapat mempengaruhi perusahaan dalam beberapa aspek. Hal ini dikarenakan controlling shareholder memiliki kekuatan untuk memaksakan pendapatnya pada direksi, manajemen, dan pemegang saham minoritas. Perusahaan keluarga ditandai dengan adanya kepemilikan terkonsentrasi. Struktur kepemilikan terkonsentrasi adalah kepemilikan mayoritas oleh suatu pihak atas suatu perusahaan. Kepemilikan dalam jumlah besar tersebut menjadikan pihak tersebut memiliki kontrol yang besar atas perusahaan sehingga pemegang saham mayoritas dapat disebut juga dengan pemegang saham pengendali (controlling shareholder).

Menurut Masripah, dkk (2016) kepemilikan terkonsentrasi dapat mengurangi masalah keagenan antara pemegang saham dan manajemen. Namun, itu akan menciptakan konflik kepentingan antara pemegang saham pengendali dan pemegang saham non-pengendali karena pemisahan kontrol dan arus kas hak melalui struktur perusahaan piramida antar atau lintas-kepemilikan.

Dalam Peraturan Bank Indonesia nomor: 14/24/pbi/2012 tentang Kepemilikan Tunggal pada Perbankan Indonesia pemegang saham pengendali (controlling shareholders) adalah badan hukum dan/atau perorangan dan/atau kelompok usaha yang : 1) memiliki saham sebesar $25 \%$ (dua puluh lima perseratus) atau lebih dari jumlah saham yang dikeluarkan dan mempunyai hak suara; 2) memiliki saham kurang dari $25 \%$ (dua puluh lima perseratus) dari jumlah saham yang dikeluarkan dan mempunyai hak suara namun dapat dibuktikan telah melakukan pengendalian baik secara langsung maupun tidak langsung.

Controlling shareholders juga memiliki pengaruh besar pada kebijakan dividen. Kebijakan dividen suatu perusahaan tercermin pada Dividend Payout Ratio (DPR) yaitu persentase laba yang dibagikan dalam bentuk dividen.

Menurut Achmat dan Lailatul (2014), dividen merupakan alasan bagi investor untuk menanamkan investasinya, dimana dividen merupakan pengembalian yang akan diterimanya atas investasinya dalam perusahaan. Para investor memiliki tujuan utama untuk meningkatkan kesejahteraan dengan mengharapkan pengembalian dalam bentuk dividen maupun capital gain. Besarnya dividen ini dapat mempengaruhi harga saham. Apabila dividen yang dibayar tinggi, maka harga saham cenderung tinggi sehingga corporate value juga tinggi. Sebaliknya bila dividen yang dibayarkan kecil maka harga saham perusahaan tersebut juga rendah. Kemampuan membayar dividen erat hubungannya dengan kemampuan perusahaan memperoleh laba. Jika perusahaan 
memperoleh laba yang besar, maka kemampuan membayar dividen juga besar.

Menurut peraturan perundangan yang berlaku bahwa perusahaan diperkenankan untuk mengambil cadangan dari net income after tax sampai cadangan mencapai $20 \%$ dari modal yang ditempatkan. Modal yang ditempatkan adalah modal yang disetor penuh ditambah modal yang belum disetor sehubungan dengan penerbitan saham seperti Right Isuue dan Waran. Jumlah laba ditahan dan dividen yang akan dibagi diputuskan dalam Rapat Umum Pemegang Saham (RUPS). Keputusan tersebut merupakan usulan dari Dewan Direksi (Board of Directors). (Hadi, Nor, 2015).

Menurut Sumanti dan Marjam (2015), Kebijakan dividen adalah salah satu fungsi seorang manajer keuangan yang mempunyai keistimewaan khusus, yaitu kebijakan dividen yang merupakan satu-satunya peran manajer keuangan yang terkait langsung dengan para pemegang saham dengan membayarkan keuntungan perusahaan langsung kepada para pemegang saham dibandingkan dengan dua fungsi manajer keuangan lainnya (menetapkan investasi dan pembiayaan) yang hanya terkait dengan perusahaan tersebut.

Hasil penelitian Jayanti dan Ayu (2017) menguji pengaruh struktur kepemilikan perusahaan terhadap kebijakan dividen. Penelitian ini menggunakan empat variabel independen yaitu kepemilikan manajerial, kepemilikan institusional, kepemilikan asing, konsentrasi kepemilikan, dan free cash flow menunjukkan dimana kepemilikan manajerial berpengaruh positif dan signifikan pada kebijakan dividen, kepemilikan institusional tidak berpengaruh signifikan pada kebijakan dividen, kepemilikan asing tidak berpengaruh signifikan terhadap kebijakan dividen, konsentrasi kepemilikan berpengaruh positif dan signifikan terhadap kebijakan dividen, serta free cash flow berpengaruh positif dan signifikan terhadap kebijakan dividen.

Sedangkan hasil penelitian Mawarni dan Made (2015) yang menguji pengaruh kesempatan investasi, leverage, dan likuiditas pada kebijakan dividen dimana kesempatan investasi secara parsial berpengaruh negatif dan signifikan pada kebijakan dividen, leverage secara parsial berpengaruh negatif dan signifikan pada kebijakan dividen, serta likuiditas secara parsial berpengaruh positif dan signifikan pada kebijakan dividen.

Berdasarkan uraian latar belakang masalah di atas, maka permasalahan dalam penelitian ini adalah bagaimanakah pengaruh keputusan investasi terhadap corporate value, bagaimanakah pengaruh controlling shareholders terhadap corporate value, bagaimanakah pengaruh kebijakan deviden terhadap corporate value.

\section{Tinjauan Pustaka}

Menurut Rinnaya, dkk (2016), corporate value merupakan kondisi tertentu yang telah dicapai oleh suatu perusahaan sebagai gambaran dari kepercayaan masyarakat terhadap perusahaan setelah melalui suatu proses kegiatan selama beberapa tahun, yaitu sejak perusahaan tersebut didirikan sampai dengan saat ini. Meningkatnya nilai perusahaan adalah sebuah prestasi, yang sesuai dengan keinginan para pemiliknya, karena dengan meningkatnya nilai perusahaan, maka kesejahteraan para pemilik juga akan meningkat.

Jadi Corporate Value adalah kinerja perusahaan yang dicerminkan oleh harga saham yang dibentuk oleh permintaan dan penawaran di pasar modal yang merefleksikan penilaian masyarakat terhadap kinerja perusahaan. Semakin tinggi nilai perusahaan semakin tinggi pula kemakmuran pemegang saham

Menurut Purnama (2016), Signaling teory menjelaskan bahwa pengeluaran investasi memberikan sinyal positif tentang pertumbuhan perusahaan dimasa yang akan datang, sehingga meningkatkan harga saham sebagai indikator nilai perusahaan. Keputusan investasi (PER) yang tinggi menunjukkan investasi perusahaan yang bagus dan prospek pertumbuhan perusahaan yang 
bagus sehingga para investor akan tertarik. Permintaan saham yang tinggi akan membuat para investor menghargai nilai saham lebih besar dari pada nilai yang tercatat pada neraca perusahaan, sehingga PBV perusahaan tinggi dan nilai perusahaan pun tinggi.

Penelitian yang dilakukan oleh Pamungkas dan Abriyani (2013), Ayem dan Ragil (2016), menemukan hasil bahwa Keputusan Investasi (PER) memberikan pengaruh positif terhadap corporate value. Hal ini mengindikasikan bahwa semakin besar dana yang dinvestasikan, maka akan semakin besar nilai perusahaan.

Ha1 : Keputusan Investasi berpengaruh positif terhadap corporate value.

Menurut Setianto dan Putri (2017) keluarga merupakan jenis controlling shareholders yang paling banyak ditemui. Controlling shareholers merupakan pihak yang memiliki kontrol yang besar atas perusahaan sehingga disebut juga dengan pemegang saham mayoritas. Anggota keluarga memiliki sejumlah besar kekayaan yang diinvestasikan dalam perusahaan ingin tetap mengontrol perusahaan dalam jangka panjang sehingga anggota keluarga tidak dapat menjual saham untuk diversifikasi kekayaan mereka.

Penelitian yang dilakukan oleh Anita dan Arief (2016), Setiawan, dkk (2016), tentang pengaruh struktur kepemilikan terhadap kebijakan dividen dan nilai perusahaan memberikan pengaruh bahwa struktur kepemilikan berpengaruh positif dan siginifikan terhadap kebijakan dividen dan nilai perusahaan.

$\mathrm{Ha} 2$ :Controlling shareholders berpengaruh positif terhadap corporate value.

Achmad dan Lailatul (2014) mengemukakan bahwa sebuah perusahaan pada dasarnya dapat membagikan laba sebagai dividen atau ditahan untuk diinvestasikan kembali. Apabila perusahaan memilih untuk membagikan laba sebagai dividen, maka akan mengurangi laba yang ditahan dan selanjutnya mengurangi total sumber dana internal. Sebaliknya jika perusahaan memilih untuk menahan laba yang diperoleh, maka kemampuan pembentukan dana intern akan semakin besar. $D P R$ yang ditetapkan oleh perusahaan akan mempengaruhi pertumbuhan perusahaan. Rasio ini menunjukkan persentase laba perusahaan yang dibayarkan kepada pemegang saham biasa perusahaan berupa dividen kas.

Penelitian yang dilakukan oleh Hidayah dan Dini (2016), Sumanti dan Marjam (2015) tentang pengaruh kebijakan dividen (DPR) terhadap nilai perusahaan menunjukkan hasil kebijakan dividen (DPR) tidak berpengaruh signifikan terhadap nilai perusahaan. Hal ini mengindikasikan peningkatan nilai dividen tidak selalu diikuti dengan meningkatnya nilai perusahaan. Karena nilai perusahaan ditentukan oleh kemampuan perusahaan dalam menghasilkan laba dari asset-aset perusahaan atau kebijakan investasinya.

Ha3 : kebijakan dividen tidak berpengaruh signifikan terhadap corporate value.

\section{Metodologi Penelitian}

Populasi adalah wilayah generalisasi yang terdiri atas obyek atau subyek yang mempunyai kualitas dan karakteristik tertentu yang ditetapkan oleh peneliti untuk dipelajari dan kemudian ditarik kesimpulannya (Sugiyono, 2015). Populasi yang akan diamati dalam penelitian ini adalah seluruh perusahaan manufaktur yang terdaftar di Bursa Efek Indonesia tahun 2014-2016 yang berjumlah 143 perusahaan.

Sampel adalah bagian dari jumlah dan karakteristik yang dimiliki oleh populasi tersebut (Sugiyono, 2015). Pemilihan sampel dilakukan dengan teknik purposive sampling, yaitu metode penentuan sampel dengan pertimbangan tertentu (Sugiyono, 2012). Kriteria dalam penelitian ini 
adalah perusahaan yang melaporkan annual report perusahaan selama tahun 2014-2016 dan memiliki data yang lengkap terkait dengan variabel yang digunakan dalam penelitian.

\section{Pengukuran Variabel dan Defenisi Operasional Variabel}

Penelitian ini menggunakan satu variabel dependen, tiga variabel independen dan 2 variabel kontrol. Definisi operasional masing-masing variabel dalam penelitian ini sebagai berikut. Variabel dependen (Y) adalah variabel yang keberadaannya dipengaruhi oleh variabel-variabel lain yang mempengaruhinya. Biasanya disebut variabel terikat. Variabel terikat pada penelitian ini adalah Corporate Value.

Corporate Value adalah kinerja perusahaan yang dicerminkan oleh harga saham yang dibentuk oleh permintaan dan penawaran di pasar modal yang merefleksikan penilaian masyarakat terhadap kinerja perusahaan, Harmono (2016), Corporate Value dihitung menggunakan rasio PBV, dengan rumus:

$$
\mathrm{PBV}=\frac{\text { Harga Per Lembar Saham }}{\text { Nilai Buku Per Lembar }} \times 100 \%
$$

Sudana (2015), PER adalah Rasio untuk mengukur bagaimana investor menilai prospek pertumbuhan perusahaan di masa yang akan datang, dan tercermin pada harga saham yang bersedia dibayar oleh investor untuk setiap rupiah laba yang diperoleh perusahaan. Price Earning Ratio dirumuskan sebagai berikut :

$$
\text { PER }=\frac{\text { Market Price per Share }}{\text { Earning Per Share }}
$$

Rumus untuk mencari controlling shareholders adalah sebagai berikut (Siregar, 2007) :

\section{Cash Flow Right (CFR)}

Hak aliran kas (CFR) adalah penjumlahan hak aliran kas langsung dan hak aliran kas tidak langsung. Rumus perhitungannya adalah :

$\mathrm{CFR}=$ Hak aliran kas langsung + Hak aliran kas tidak langsung

Hak aliran kas langsung $=$ Presentase kepemilikan atas nama sendiri

Hak aliran kas tidak langsung $=$ Perkalian \% kepemilikan dalam setiap rantai kepemilikan.

\section{Control Right (CR)}

Hak kontrol merupakan hak suara untuk ikut serta dalam menentukan kebijakan penting perusahaan. Rumus perhitungannya adalah :

$$
\text { Hak kontrol langsung + Hak kontrol tidak langsung }
$$

Hak kontrol langsung $=$ Persentase kepemilikan atas nama diri sendiri. Hak kontrol tidak langsung $=$ Jumlah kepemilikan minimum di setiap rantai kepemilikan.
3. Cash Flow Right Leverage (CFRL) 
Cash flow right leverage merupakan penyimpangan hak aliran kas dari hak kontrol yang dimiliki oleh pemegang saham dengan menggunakan berbagai mekanisme kepemilikan seperti piramida dan lintas kepemilikan. Rumus perhitungannya adalah :

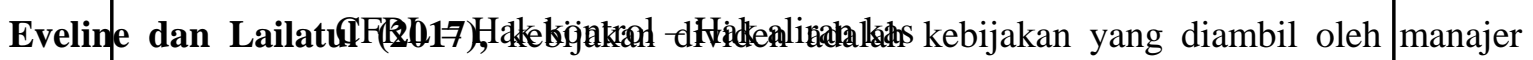
keuangan yang berhubungan dengan keputusan apakah dividen suatu periode akan dibagikan kepada pemegang saham atal apakah dividen tersebut akan ditahan dan tidak dibagi untuk kepentingan pengembangan dan ekspansi perusahaan. Dividend Pay Out Ratio sebagai berikut, dihitung dengan rumus (Sudana, 2015):

$$
\mathrm{DPR}=\frac{\text { Dividend Per Share }}{\text { Earning Per Share }}
$$

Menurut Sugiyono (2012) Variabel kontrol adalah variabel yang membuat konstan hubungan variabel bebas terhadap variabel terikat. Sehingga variabel terikat tidak dipengaruhi faktor luar yang tidak diteliti. Variabel kontrol sering digunakan sebagai pembanding melalui penelitian eksternal. Penelitian ini menggunakan dua variabel kontrol untuk mengendalikan faktor-faktor lain yang mempengaruhi struktur modal. Variabel kontrol yang digunakan adalah firm size dan kinerja perusahaan (ROA).

Analisis data yang dilakukan adalah analisis kuantitatif yang dinyatakan dengan angka-angka dan perhitungannya menggunakan metode statistik yang dibantu dengan program eviews.9. Analisa data yang digunakan dalam penelitian ini yaitu pengujian deskriptif, asumsi klasik, analisis regresi data panel dan uji hipotesis.

\section{Pemilihan Model Regresi Data Panel}

Menurut Ajija, dkk (2011) ada 3 pendekatan yang bisa digunakan untuk mengestimasi model regresi data panel yaitu Pooled least square (Commond Effect), Fixed Effect dan Random Effect.Untuk menentukan metode mana yang paling tepat dalam mengestimasi model regresi data panel maka perlu dilakukan uji spesifikasi model yang terdiri dari uji chow dan uji hausman.

1. Uji Chow

Uji Chow digunakan untuk menentukan model analisis data panel yang akan digunakan. Uji Chow digunakan untuk memilih antara model Fixed Effect atau model Common Effect yang sebaiknya dipakai. /

$$
\begin{aligned}
& \text { H0 : Common Effect } \\
& \text { Ha : Fixed Effect }
\end{aligned}
$$

Apabila hasil uji spesifikasi ini menunjukkan probabilitas Chi- square lebih dari 0,05 maka model yang dipilih adalah Common Effect. Sebaliknya, apabila probabilitas Chi-square kurang dari 0,05 maka model yang sebaiknya dipakai adalah Fixed Effect.

2. Uji Hausman

Uji Hausman digunakan untuk mengetahui model yang sebaiknya dipakai, yaitu Fixed Effect model (FEM) atau random effect model (REM). Hipotesis dalam uji hausman sebagai berikut:

$$
\begin{aligned}
& \text { H0 : Random Effect Model } \\
& \text { Ha : Fixed Effect Model }
\end{aligned}
$$


Apabila hasil uji spesifikasi ini menunjukkan probabilitas Chi- square lebih dari 0,05 maka model yang dipilih adalah Random Effect. Sebaliknya, apabila probabilitas Chi-square kurang dari 0,05 maka model yang sebaiknya dipakai adalah Fixed Effect.

\section{Analisis Regresi Data Panel}

Menurut Ajija, dkk (2011), data panel atau pooled data merupakan kombinasi dari data time series dan cross-section. Analisis data panel memiliki tujuan yang sama dengan analisis regresi linear berganda yaitu untuk mengetahui pengaruh variabel bebas terhadap variabel tidak bebas (terikat) atas perubahan dari setiap peningkatan atau penurunan variabel bebas yang akan mempengaruhi variabel terikat. Persamaan analisis regresi data panel dalam penelitian ini dapat dirumuskan sebagai berikut (Ningrum dan Maswar, 2017) :

$\mathrm{PBV}=\alpha+\beta_{1} \mathrm{PER}+\beta_{2} \mathrm{CS}+\beta_{3} \mathrm{DPR}+\mathrm{e}$

Dimana :

PBV : Price Book Value

$\alpha \quad$ : Konstanta

PER : Price Earning Ratio

CS : Controlling Shareholders

DPR : Dividend Payout Ratio

$\beta_{1}, \beta_{2}, \beta_{3} \quad$ : Koefisien Regresi

e : Error

\section{Hasil dan Pembahasan}

Sampel pada penelitian ini ditentukan berdasarkan kriteria yang mendukung penelitian. Populasi penelitian ini adalah seluruh perusahaan manufaktur yang terdaftar di Bursa Efek Indonesia dengan jumlah 143 perusahaan. Sampel penelitian adalah sebanyak 131 perusahaan atau sebesar $92,3 \%$ dari total populasi

Uji deskriptif adalah analisis yang dilakukan dengan menggambarkan dan mendeskripsikan secara ringkas mengenai data yang digunakan dalam penelitian. Uji deskriptif dapat juga dikatakan merupakan metode pengumpulan, mengolah, menyajikan, dan menganalisa data kuantitatif secara deskriptif. Statistik deskriptif dapat memberikan gambaran atau deskripsi dari suatu data yang dilihat dari nilai minimum, maximum, rata-rata (mean) dan standar deviasi Ghozali (2011).

Sebagai tinjauan awal terhadap data penelitian, berikut ini akan disajikan ringkasan data-data dalam bentuk statistik deskriptif untuk masing-masing variabel sebagai berikut :

\section{Tabel 2. Hasil Statistic Deskriptif}

\begin{tabular}{cccccccc} 
& & & & & Median & Std. \\
& & Observations & Min & Max & & Mean & $\begin{array}{c}\text { Stdian } \\
\text { Deviation }\end{array}$ \\
\hline PBV (\%) & 393 & 0,000 & 4,000 & 2,000 & 2,257 & 0,646 \\
PER $($ Rp) & 393 & $-1,000$ & 2,000 & 1,000 & 1,145 & 0,463 \\
CS & $(\%)$ & 393 & 1,000 & 2,000 & 2,000 & 1,816 & 0,389 \\
DPR $(\%)$ & 393 & 0,000 & 2,000 & 1,000 & 1,475 & 0,533 \\
FS & $($ Rp $)$ & 393 & 1,000 & 2,000 & 1,000 & 1,061 & 0,421
\end{tabular}




\begin{tabular}{lllllll} 
ROA $(\%)$ & 393 & $-1,000$ & 4,000 & 1,000 & 0,827 & 0,652 \\
\hline
\end{tabular}

\section{- Pengujian dan Analisis Data}

Uji asumsi klasik dilakukan untuk mengetahui kondisi data yang ada agar dapat menentukan model yang paling tepat digunakan Ghozali (2011). Uji asumsi klasik dalam penelitian ini terdiri dari uji normalitas, uji multikolonieritas, uji heterokedastisitas dan uji autokolerasi. Untuk menguji normalitas data digunakan Normal P-P Plot, uji multikolinearitas dengan menggunakan nilai Tolerance dan variance inflation factor (VIF), uji heterokedastitas dengan menggunakan Scatterplot, dan uji autokorelasi dengan menggunakan Durbin-Wattson.

Uji normalitas dapat ditempuh dengan Uji Jarque-Berra (JB test). Dalam penelitian ini dilakukan transformasi data dalam bentuk log. Transformasi data dilakukan pada beberapa variabel, yaitu pada variabel keputusan investasi, controlling shareholder dan kebijakan deviden agar residual berdistribusi normal. Residual dalam model penelitian ini telah berdistribusi normal.

Tabel 3. Uji Multikolinearitas

\begin{tabular}{llllll}
\hline & PER & CS & DPR & FS & ROA \\
\hline PER & 1.000000 & & & & \\
CS & 0.055909 & 1.000000 & & & \\
DPR & -0.053333 & 0.153593 & 1.000000 & & \\
FS & -0.181110 & 0.121653 & 0.033963 & 1.000000 & \\
ROA & -0.083643 & 0.161461 & 0.237872 & -0.003399 & 1.000000 \\
\hline
\end{tabular}

Pada tabel diatas terlihat bahwa masing-masing variabel independen yang digunakan telah memiliki koefisien korelasi dibawah 0,80 sehingga dapat disimpulkan bahwa masing-masing variabel independen yang digunakan terbebas dari gejala multikolinearitas.

Pada penelitian ini telah dilakukan uji heteroskedastisitas dan hasilnya terlihat bahwa data penelitian terbebas dari masalah heteroskedastisitas.

\section{-Hasil Pemilihan Model Regresi Data Panel}

\section{Uji Chow}

Uji Chow digunakan untuk menentukan model analisis data panel yang akan digunakan. Uji Chow digunakan untuk memilih antara model Fixed Effect atau model Common Effect yang sebaiknya dipakai.

$$
\begin{aligned}
& \text { H0 : Common Effect } \\
& \text { Ha : Fixed Effect }
\end{aligned}
$$

Apabila hasil uji spesifikasi ini menunjukkan probabilitas Chi-square lebih dari 0,05 maka model yang dipilih adalah Common Effect. Sebaliknya, apabila probabilitas Chi-square 
kurang dari 0,05 maka model yang sebaiknya dipakai adalah Fixed Effect. Hasil uji spesifikasi model adalah sebagai berikut :

Tabel 4. Hasil Uji Chow

\begin{tabular}{llll}
\hline Effects Test & Statistic & d.f. & Prob. \\
\hline Cross-section F & 5.601 & $(71,102)$ & 0.000 \\
Cross-section Chi-square & 284.424 & 71 & 0.000 \\
& & & \\
\hline
\end{tabular}

Berdasarkan hasil uji di atas, dapat diketahui bahwa probabilitas Chi-square adalah 0,000 lebih kecil dari 0,05 maka dapat disimpulkan H0 ditolak dan model Fixed Effect lebih baik dibandingkan dengan model Common Effect. Ketika model yang terpilih adalah Fixed Effect maka perlu dilakukan uji lagi, yaitu uji Hausman. Uji Hausman dilakukan untuk mengetahui apakah model fixed effect atau model random effect yang akan digunakan dalam penelitian ini.

\section{Uji Hausman}

Uji Hausman digunakan untuk mengetahui model yang sebaiknya dipakai, yaitu Fixed Effect Model (FEM) atau Random Effect Model (REM). Hipotesis dalam uji hausman sebagai berikut:

$$
\begin{aligned}
& \text { H0 : Random Effect Model } \\
& \text { Ha : Fixed Effect Model }
\end{aligned}
$$

Apabila hasil uji spesifikasi ini menunjukkan probabilitas Chi-square lebih dari 0,05 maka model yang dipilih adalah Random Effect. Sebaliknya, apabila probabilitas Chi-square kurang dari 0,05 maka model yang sebaiknya dipakai adalah Fixed Effect. Hasil estimasi uji Hausmann adalah sebagai berikut:

Tabel 5. Hasil Uji Hausman

\begin{tabular}{llll}
\hline Test Summary & Chi-Sq. Statistic & Chi-Sq. d.f. & Prob. \\
& & & \\
\hline Cross-section random & 36.868 & 5 & 0.000 \\
\hline
\end{tabular}

Berdasarkan hasil uji di atas, dapat diketahui bahwa probabilitas Chi-square adalah 0,000 lebih kecil dari 0,05 maka dapat disimpulkan H0 ditolak dan model yang digunakan sebaiknya adalah model Fixed Effect.

\section{-Hasil Analisis Regresi Data Panel}

Berdasarkan pemilihan model yang telah dilakukan, model yang sebaiknya digunakan adalah model Fixed Effect. Kemudian sebelum pemilihan model, data dinyatakan telah lolos 
dari uji asumsi klasik, sehingga hasil estimasi konsisten dan tidak bias. Hasil estimasi model regresi data panel sebagai berikut:

Tabel 6. Hasil Estimasi Fixed Effect Model

\begin{tabular}{lllll}
\hline \hline Variable & Coefficient & Std. Error & t-Statistic & Prob. \\
\hline \hline C & 1.562 & 0.686 & 2.278 & 0.025 \\
PER & 0.237 & 0.080 & 2.942 & 0.004 \\
CS & -0.059 & 0.256 & -0.232 & 0.817 \\
DPR & 0.103 & 0.078 & 1.328 & 0.187 \\
FS & 0.294 & 0.420 & 0.700 & 0.485 \\
ROA & 0.081 & 0.072 & 1.123 & 0.264 \\
\hline \hline
\end{tabular}

- Keputusan Investasi

Berdasarkan hasil yang diperoleh dari pengujian terhadap regresi, di dapatkan nilai koefisien regresi sebesar 0,237 dan memiliki tstatistic sebesar 2,942 dengan probabilitynya 0,004 dengan tingkat signifikansi sebesar 0,05. Hal ini menunjukkan bahwa variabel keputusan investasi yang diproksikan dengan Price Earning Ratio (PER) berpengaruh positif dan signifikan terhadap corporate value yang diproksikan dengan Price Book Value (PBV) pada perusahaan manufaktur yang terdaftar di Bursa Efek Indonesia pada tahun 2014-2016.

Hasil pengujian pengaruh keputusan investasi terhadap corporate value konsisten dengan uraian teori dan hipotesis yang diajukan. Dimana keputusan investasi berpengaruh positif terhadap corporate value. Dalam hal ini adanya pengaruh keputusan investasi terhadap nilai perusahaan menunjukkan bahwa, jika manajer berhasil menciptakan keputusan investasi yang tepat maka aset yang diinvestasikan akan menghasilkan kinerja yang optimal sehingga memberikan suatu sinyal positif kepada investor yang nantinya akan meningkatkan harga saham dan nilai perusahaan. Investasi yang tinggi yang dilakukan perusahaan, maka akan meningkatkan nilai perusahaan. Investasi yang tinggi merupakan sinyal pertumbuhan pendapatan perusahaan di masa yang akan datang. Sinyal tersebut akan dianggap sebagai good news yang nantinya akan mempengaruhi persepsi investor terhadap kinerja perusahaan yang akhirnya akan mempengaruhi nilai perusahaan. Oleh karena itu, manajer harus menjaga perkembangan investasi sehingga dapat mencapai tujuan perusahaan melalui kesejahteraan pemegang saham dan dapat meningkatkan nilai perusahaan.

Hasil penelitian ini menunjukkan hasil yang sama dengan penelitian yang dilakukan oleh Pamungkas dan Abriyani (2013), Ayem dan Ragil (2016) dan Rahmawati, dkk (2015) dan Ningrum dan Maswar (2017) dimana keputusan investasi (PER) berpengaruh positif signifikan terhadap corporate value.

\section{- Controlling Shareholders}


Berdasarkan hasil yang diperoleh dari pengujian terhadap regresi, di dapatkan nilai koefisien regresi sebesar $-0,059$ dengan nilai tstatistic sebesar $-0,232$ serta probability sebesar 0,817 dan tingkat signifikansi sebesar 0,05. Hal ini menunjukkan bahwa variabel Controlling Shareholders yang diproksikan dengan cash flow right leverage (CFRL) tidak berpengaruh terhadap corporate value yang diproksikan dengan Price Book Value (PBV) pada perusahaan manufaktur yang terdaftar di Bursa Efek Indonesia pada tahun 2014-2016. Hal ini berarti controlling shareholders perusahaan tidak mampu mempengaruhi penilaian pasar terhadap perusahaan.

Hasil penelitian ini sejalan dengan hasil penelitian Bernandhi dan Muid (2014) dan Limbago dan Juniarti (2014) dimana CS tidak berpengaruh signifikan terhadap corporate value (PBV). Namun penelitian tidak konsisiten dengan penelitian Anita dan Arief (2016), dimana sebagian controlling shareholders terdapat dalam kepemilikan manajerial mampu mempengaruhi jalannya perusahaan yang pada akhirnya berpengaruh pada kinerja perusahaan dalam mencapai tujuan perusahaan, yaitu mengoptimalkan nilai perusahaan yang terjadi karena adanya pengendalian yang dimiliki.

\section{-Kebijakan Dividen}

Berdasarkan hasil yang diperoleh dari pengujian terhadap regresi, di dapatkan nilai koefisien regresi sebesar 0,103 serta memiliki tstatistic sebesar 1,328 dengan probability sebesar 0,187 dengan tingkat signifikansi sebesar 0,05. Hal ini menunjukkan bahwa variabel kebijakan dividen yang diproksikan dengan Dividend Payout Ratio (DPR) tidak berpengaruh terhadap corporate value yang diproksikan dengan price book value (PBV) pada perusahaan manufaktur yang terdaftar di Bursa Efek Indonesia pada tahun 2014-2016.

Hasil penelitian ini konsisten dengan uraian teori dan hipotesis yang diajukan sebelumnya. Dimana kebijakan dividen (DPR) tidak berpengaruh signifikan terhadap corporate value (PBV) perusahaan manufaktur yang terdaftar di BEI pada tahun 2014-2016. Kebijakan dividen tidak berpengaruh terhadap nilai perusahaan, dikarenakan hasil penelitian ini sejalan dengan teori yang dikemukakan oleh Miller dan Modligiani yang menyatakan bahwa kebijakan dividen tidak mempengaruhi nilai perusahaan karena menurut mereka rasio pembayaran dividen hanyalah rincian dan tidak mempengaruhi kesejahteraan pemegang saham. Meningkatnya nilai dividen tidak selalu diikuti dengan meningkatnya nilai perusahaan. Karena nilai perusahaan ditentukan oleh kemampuan perusahaan dalam menghasilkan laba dari asset-aset perusahaan atau kebijakan investasinya.

Adanya pengaruh yang tidak signifikan dari variabel kebijakan dividen terhadap corporate value menunjukkan tinggi rendahnya dividen yang dibayarkan kepada pemagang saham, tidak berkaitan dengan tinggi rendahnya nilai perusahaan. Perusahaan yang dapat memberikan dividen tinggi akan mendapatkan nilai kepercayaan yang tinggi dari para investor, karena investor lebih menyukai kepastian tentang returns investasinya dan mengantisipasi risiko ketidakpastian tentang kebangkrutan perusahaan.

Hasil penelitian ini membenarkan teori bird in the hand bahwa para pemegang saham lebih menyukai pembagian laba dalam bentuk dividen saat ini dibandingkan dengan pembagian laba dalam bentuk capital gain di masa mendatang. Sejalan dengan itu hal ini sesuai dengan hipotesis kebijakan dividen relevan, bahwa perusahaan dengan pembayaran dividen yang besar kepada pemegang sahamnya dapat meningkatkan nilai perusahaan, karena investor akan menginvestasikan dananya pada suatu perusahaan yang membagi labanya dalam bentuk dividen secara konsisten. Hasil penelitian ini sejalan dengan hasil penelitian yang dilakukan oleh Hidayah dan Dini (2016), Sofyaningsih dan Pancawati (2011), Anita dan Arief (2016) dan Alipudin dan Nur (2014)dimana DPR tidak berpengaruh signifikan terhadap corporate value (PBV). 


\section{-Firm Size}

Berdasarkan hasil yang diperoleh dari pengujian terhadap regresi, di dapatkan nilai koefisien regresi sebesar 0,294 serta memiliki tstatistic sebesar 0,700 dengan probability sebesar 0,485 dengan tingkat signifikansi sebesar 0,05. Hal ini menunjukkan bahwa variabel firm size yang diproksikan dengan (FS) tidak berpengaruh terhadap corporate value yang diproksikan dengan price book value (PBV) pada perusahaan manufaktur yang terdaftar di Bursa Efek Indonesia pada tahun 2014-2016.

Firm Size yang tidak berpengaruh memiliki makna bahwa ukuran perusahaan bukan merupakan pertimbangan bagi investor dalam berinvestasi. Nilai positif memberikan makna bahwa meningkatnya ukuran perusahaan akan meningkatkan nilai perusahaan. Ukuran perusahaan dinilai dari total aset yang dimiliki perusahaan untuk kegiatan operasionalnya. Semakin besar perusahaan maka semakin besar pula dana yang dibutuhkan untuk kegiatan operasional perusahaan. Salah satu sumber dana perusahaan diperoleh dari hutang yang berasal dari pihak eksternal. Jadi dapat disimpulkan bahwa semakin besar perusahaan maka semakin besar pula hutang yang dimilikinya.

Penarikan hutang yang dilakukan perusahaan besar seharusnya mampu membuat perusahaan memperoleh pengembalian berupa aset yang besar pula. Aset yang dijadikan jaminan untuk memperoleh hutang tersebut lebih besar nilainya daripada pengembalian aset yang diterima perusahaan. Sehingga, hal tersebut menunjukkan kurang solvabilitasnya antara aset dan hutang pada perusahaan. Ketidaksolvabilitasan pada perusahaan menimbulkan kekhawatiran bagi para investor. Hal tersebut disebabkan oleh tingginya risiko dalam perusahaan tersebut sehingga memperbesar potensi terjadinya kebangkrutan. Hasil penelitian ini menunjukkan hasil yang sama dengan Rahmawati, dkk (2015) dan Limbago dan Juniarti (2014) dimana firm size secara parsial tidak berpengaruh signifikan dengan arah hubungan positif terhadap corporate value.

\section{-Kinerja}

Berdasarkan hasil yang diperoleh dari pengujian terhadap regresi, di dapatkan nilai koefisien regresi sebesar 0,081 serta memiliki tstatistic sebesar 1,123 dengan probability sebesar 0,264 dengan tingkat signifikansi sebesar 0,05. Hal ini menunjukkan bahwa variabel kinerja perusahaan yang diproksikan dengan Return On Asset (ROA) tidak berpengaruh terhadap corporate value yang diproksikan dengan price book value (PBV) pada perusahaan manufaktur yang terdaftar di Bursa Efek Indonesia pada tahun 2014-2016. Tidak adanya pengaruh variabel ROA terhadap PBV mengindikasikan bahwa tinggi rendahnya Profitabilitas tidak dapat menjelaskan dan memprediksi nilai perusahaan.

Hasil penelitian ini tidak sesuai dengan hasil penelitian Nurhayati (2013), Sumanti dan Marjam (2015) dan Nugraha dan Kurnia (2017) di mana variabel ROA berpengaruh positif signifikan terhadap corporate value. Kinerja keuangan menunjukkan prestasi yang dicapai oleh perusahaan dalam suatu periode tertentu. Jika kinerja keuangan menunjukkan prospek yang baik, maka saham tersebut akan diminati oleh para investor dan berpengaruh pada nilai jual saham tersebut. Pengukuran kinerja keuangan dapat dilakukan dengan penilaian analisis laporan keuangan. Analisis rasio keuangan merupakan dasar untuk menilai dan menganalisis prestasi operasi perusahaan atau kinerja perusahaan. Rasio keuangan dirancang untuk mengevaluasi laporan keuangan, yang berisi data tentang posisi perusahaan pada suatu titik dan operasi perusahaan pada masa lalu.

Nilai nyata laporan keuangan terletak pada fakta bahwa laporan keuangan dapat digunakan untuk membantu memperkirakan pendapatan dan dividen masa yang akan datang. Rasio keuangan yang merupakan bentuk informasi akuntansi yang penting bagi perusahaan selama suatu periode tertentu. Berdaarkan rasio tersebut, dapat dilihat keuangan yang dapat mengungkapkan posisi, kondisi keuangan, maupun kinerja ekonomis di masa depan dengan kata lain informasi akuntansi. Hasil penelitian ini konsisten dengan penelitian Ustiani (2015) di mana tidak adanya pengaruh 
positif antara profitabilitas dengan corporate value. Hal ini mengindikasikan bahwa tinggi rendahnya Profitabilitas tidak dapat menjelaskan dan memprediksi nilai perusahaan.

$-\mathbf{U j i} \mathbf{F}$

Tabel 7. Hasil Uji F-Statistk

\begin{tabular}{ll} 
F-statistic & 9.934 \\
\hline
\end{tabular}

Prob(F-statistic) 0.000

Berdasarkan tabel diatas menunjukkan nilai F-statistik sebesar 9,934 dan probability sebesar 0,000 dengan tingkat kesalahan yang digunakan sebesar 0,05 . Hasil yang diperoleh menunjukkan bahwa nilai probability yang dihasilkan sebesar $0,000<0,05$ maka keputusannya adalah bahwa keputusan investasi, controlling shareholders, kebijakan dividen, firm size dan kinerja perusahaan berpengaruh positif dan signifikan secara bersama-sama terhadap corporate value pada perusahaan manufaktur yang terdaftar di Bursa Efek Indonesia pada tahun 2014-2016.

\section{-Analisis Koefisien Determinasi $\left(\mathbf{R}^{2}\right)$}

Tabel 8. Hasil Uji Koefisien Determinasi $\left(\mathbf{R}^{2}\right)$

\begin{tabular}{ll}
\hline R-squared & 0.881 \\
Adjusted R-squared & 0.792 \\
\hline
\end{tabular}

Berdasarkan tabel atas menunjukkan bahwa nilai koefisien determinasi yang dihasilkan dalam pengujian Adjusted $R$-squared bernilai 0,792. Hasil yang diperoleh menunjukkan bahwa variabel keputusan investasi, controlling shareholders, kebijakan dividen, firm size, dankinerja perusahaan mampu memberikan kontribusi dalam mempengaruhi nilai corporate value sebesar 79,2\% sedangkan sisanya 20,8\% lagi dipengaruhi oleh variabel lain yang tidak dimasukkan dalam model.

\section{Kesimpulan}

Keputusan investasi yang diproksikan dengan Price Aarning Ratio (PER) berpengaruh positif dan signifikan terhadap corporate value yang diproksikan dengan Price Book Value (PBV). Controlling shareholders yang diproksikan dengan Cash Flow Right Leverage (CFRL) dan Kebijakan dividen yang diproksikan dengan Dividend Payout Ratio (DPR) tidak berpengaruh terhadap corporate value yang diproksikan dengan Price Book Value (PBV). Firm size yang diproksikan dengan $\mathrm{Ln}$ (Total Asset) tidak berpengaruh terhadap corporate value yang diproksikan dengan Price Book Value (PBV). Kinerja perusahaan yang diproksikan dengan Return on Asset (ROA) tidak berpengaruh terhadap corporate value yang diproksikan dengan Price Book Value (PBV).

\section{Ucapan Terimakasih}

Kami mengucapkan terimakasih kepada Ketua Yayasan Perguruan Tinggi Komputer (YPTK) Padang Bapak H. Herman Nawas beserta Ibu Dr. Hj. Zerni Melmusi, SE, MM, Ak, CA yang telah 
memberikan dukungan moril dan materil kepada kami dan ucapan terimakasih juga saya persembahkan kepada bapak Rektor UPI YPTK Padang Prof. Dr. H. Sarjon Defit, S.Kom, M.Sc yang telah memotivasi sehingga penelitian ini selesai ditulis.

\section{Daftar Pustaka}

Achmad, Safitri Lia dan Lailatul Amanah. 2014. "Pengaruh Keputusan Investasi, Keputusan Pendanaan, Kebijakan Dividen dan Kinerja Keuangan Terhadap Nilai Perusahaan". Jurnal Ilmu dan Riset Akuntansi. Vol.3 No.9.

Ajija, Shochrul Rohmatul. 2011. "Cara Cerdas Menguasai Eviews”. Jakarta: Salemba Empat.

Alipudin, Asep dan Nur Hidayat. 2014. "Keputusan Investasi, Pendanaan, Kebijakan Dividen dan Price To Book Value Perusahaan Pertambangan Di Bursa Efek Indonesia”. Jurnal Riset Akuntansi dan Perpajakan (JRAP). Vol. 1 No. 1 Juni 2014 Hal. 48-59.

Anita, Aprilia dan Arief Yulianto. 2016. "Pengaruh Kepemilikan Manajerial dan Kebijakan Dividen Terhadap Nilai Perusahaan”. Management Analysis Journal. Vol. 5 No. 1 Hal. 17-23.

Ayem, Sri dan Ragil Nugroho. 2016. "Pengaruh Profitabilitas, Struktur Modal, Kebijakan Dividen dan Keputusan Investasi Terhadap Nilai Perusahaan (Studi Kasus Perusahaan Manufaktur Yang Go Publik Di Bursa Efek Indonesia Periode 2010-2014)”. Jurnal Akuntansi. Vol. 4 No. 1 Juni 2016 Hal. 31-39.

Bernandhi, Riza dan Abdul Muid. 2014. "Pengaruh Kepemilikan Manajerial, Kepemilikan Institusional, Kebijakan Dividen, Leverage, dan Ukuran Perusahaan Terhadap Nilai Perusahaan". Diponeogoro Journal of Accounting. Vol. 3 No. 1 Hal. 1-14.

Eveline, Debby Gabriella dan Lailatul Amanah. 2017. "Pengaruh Keputusan Investasi, Pendanaan, Kebijakan Dividen dan Modal Intelektual Terhadap Nilai Perusahaan”. Jurnal Ilmu dan Riset Akuntansi. Vol. 6 No. 2 Februari 2017 Hal. 422-439.

Ghozali, Imam. 2011. “Aplikasi Analisis Multivirat dengan Program IBM SPSS 19”. Edisi kelima. Semarang: Universitas Diponegoro.

Hadi, Nor. 2015. "Pasar Modal”. Edisi kedua. Yogyakarta: Graha Ilmu.

Harmono. 2016. "Manajemen Keuangan Berbasis Balanced Scorecard Pendekatan Teori, Kasus, dan Riset Bisnis”. Jakarta: Bumi Aksara.

Hidayah, Norma dan Dini. 2016. "Pengaruh Profitabilitas, Leverage, dan Kebijakan Dividen Terhadap Nilai Perusahaan Food and Beverages". Jurnal Ilmu dan Riset Akuntansi. Vol. 5 No. 9 September 2016

Jayanti, Ida Setya Dwi dan Ayu Febrian Puspitasari. 2017. "Struktur Kepemilikan Dan Kebijakan Dividen Pada Perusahaan Manufaktur Di Indonesia". The Indonesian Journal of Applied Business. Vol. 1 No. 1 April 2017.

Limbago, Elsa dan Juniarti. "Pengaruh Family Control Terhadap Profitabilitas Dan Nilai Perusahaan Pada Industri Properti dan Real Estate”. Business Accounting Review. Vol. 2 No. 1.

Masripah, dkk. 2016. "Controlling Shareholder and Tax Avoidance: Family Ownership and Corporate Governance". International Reserach Journal of Business Studies. Vol.8 No. 3 Hal.167-180. 
Mawarni, Luh Fajarini Indah dan Ni Made Dwi Ratnadi. 2015. "Pengaruh Kesempatan Investasi, Leverage dan Likuiditas Pada Kebijakan Dividen Perusahaan Manufaktur Yang Terdaftar Di BEI”. E-Journal Akuntansi Universitas Udayana. Hal. 200-208.

Ningrum, Frista Cahya dan Maswar Patuh Priyadi. 2017. "Pengaruh Keputusan Investasi, Pendanaan, Kebijakan Dividen dan Suku Bunga Terhadap Nilai Perusahaan”. Jurnal Ilmu dan Riset Akuntansi. Vol. 6 No. 4 April 2017.

Nugraha, Muhammad Kemal dan Kurnia. 2017. "Pengaruh Kinerja Keuangan, Ukuran Perusahaan dan Keputusan Investasi Terhadap Nilai Perusahaan”. Jurnal Ilmu dan Riset Akuntansi. Vol. 6 No. 1 Januari 2017. Hal. 312-328.

Nurhayati, Mafizatun. 2013. “Pengaruh Profitabilitas, Likuiditas dan Ukuran Perusahaan Terhadap Kebijakan Dividen dan Nilai Perusahaan Sektor Non Jasa”. Jurnal Keuangan dan Bisnis. Vol. 5 No. 2 Juli 2013 Hal. 144-153.

Pamungkas, Hesti Setyorini dan Abriyani Puspaningsih. 2013. "Pengaruh Keputusan Investasi, Keputusan Pendanaan, Kebijakan Dividen dan Ukuran Perusahaan Terhadap Nilai Perusahaan. JAAI. Vol. 17 No. 2 Desember 2013 Hal. 156-165.

Purnama, Hari. 2016. "Pengaruh Profitabilitas, Kebijakan Hutang, Kebijakan Dividen, dan Keputusan Investasi Terhadap Nilai Perusahaan (Studi Kasus Perusahaan Manufaktur Yang Go Publik Di Bursa Efek Indonesia Periode 2010-2014).” Jurnal Akuntansi. Vol.4 No. 1 Juni 2016.

Rahmawati, Amalia Dewi, dkk. 2015. "Pengaruh Ukuran Perusahaan, Profitabilitas, Struktur Modal, dan Keputusan Investasi Terhadap Nilai Perusahaan (Studi pada Perusahaan Sektor Properti, Real Estate, dan Building Construction yang Terdaftar di Bursa Efek Indonesia (BEI) Periode 2010-2013)'.Jurnal Administrasi Bisnis (JAB). Vol. 23 No. 2 Juni 2015.

Rinnaya, Ista Yansi, dkk. 2016. "Pengaruh Profitabilitas, Rasio Aktivitas, Keputusan Pendanaan, dan Keputusan Investasi Terhadap Nilai Perusahaan (Studi Empiris Pada Perusahaan Manufaktur Yang Terdaftar Di BEI Tahun 2010-2014)". Journal of Accounting. Vol.2 No. 2 Maret 2016.

Setianto, Rahmat Heru dan Putri Kartika Sari. 2017. "Perusahaan Keluarga dan Kebijakan di Indonesia". Jurnal Siasat Bisnis. Vol. 21 No. 2 Hal. 107.118.

Siregar, Baldric. 2007. "Pengaruh Pemisahan Hak Aliran Kas dan Hak Kontrol Terhadap Dividen”.'Simposium Nasional Akuntansi X. Juli 2007

Sofyaningsih, Sri dan Pancawati Hardiningsih. 2011. "Struktur Kepemilikan, Kebijakan Dividen, Kebijakan Utang dan Nilai Perusahaan”. Dinamika Keuangan dan Perbankan. Vol. 3 No. 1 Hal. 68-87.

Sudana, I Made. 2015. “Manajemen Keuangan Perusahaan”. Edisi Kedua. Jakarta: Erlangga.

Sugiyono. 2012. "Metode Penelitian Pendidikan : Pendekatan Kuantitatif, Kualitatif dan R\&D. Bandung: Alfabeta.

Sugiyono. 2015. "Metode Penelitian Kuantitatif Kualitatif $R \& B$ ”. Bandung : Alfabeta.

Sumanti, Jorenza Chiquita dan Marjam Mangantar. 2015. "Analisis Kepemilikan Manajerial, Kebijakan Hutang dan Profitabilitas Terhadap Kebijakan Dividen dan Nilai Perusahaan Pada Perusahaan Manufaktur yang Terdaftar di BEI". Jurnal EMBA. Vol. 3 No. 1 Maret 2015 Hal. 1141-1151.

Ustiani, Nila. 2015. "Pengaruh Struktur Modal, Kepemilikan Manajerial, Keputusan Investasi, Kebijakan Dividen, Keputusan Pendanaan dan Profitabilitas Terhadap Nilai Perusahaan (Studi Pada Perusahaan Keuangan dan Perbankan Di BEI Tahun 2009-2013)”. Semarang: Universitas Pandanaran. 